\title{
En ungdom med luftveisplager og kortvarig feber
}

\author{
Valg av behandling på legevakt kan være utfordrende. Særlig tidlig \\ i sykdomsforløpet kan de kliniske tegnene være sparsomme, og man \\ har begrenset med diagnostiske hjelpemidler. Noen ganger er veien \\ åt skogen brolagt med gode intensjoner.
}

En gutt i tidlig tenårene kom på legevakten sammen med sin far etter ett døgn med feber, hodepine, tungpustethet, svimmelhet og ømhet i store deler av kroppen. Han hadde ikke hatt hoste. Pasienten var tidligere frisk og brukte ingen medisiner. Ved undersøkelse fremsto han ikke respiratorisk besværet, hadde ingen inndragninger og brukte ikke respiratoriske hjelpemuskler. Det hørtes milde hveselyder $i$ ekspiriet. Han hadde respirasjonsfrekvens på 20/minutt og normal pulsoksymetrisk oksygenmetning på $98 \%$. Pulsen var 120 slag/minutt, temperatur målt i øret $38,2^{\circ} \mathrm{C}$ og CRP $11 \mathrm{mg} / \mathrm{l}(<5)$. Svelget var upåfallende, han hadde normale tonsiller, ingen glandelsvulst på halsen og normalt funn ved auskultasjon av hjertet.

Pasienten hadde to år tidligere hatt gastrointestinale symptomer, inklusive dysfagi, oppkast og kvalme. Plagene var grundig unders $\emptyset$ kt på sykehus uten at det ble funnet noe galt. Han hadde året før dette hatt hjertebank og blitt utredet med 24-timers EKG og ultralyd av hjertet. Det var ingen unormale funn ved hjerteutredningen. Han hadde ingen slike plager nå.

Symptomer på luftveisinfeksjon er av de vanligste årsakene til konsultasjoner $\mathrm{i}$ allmennpraksis og på legevakt. Viral øvre luftveisinfeksjon er her en sannsynlig diagnose. Infeksjonsutløst obstruktivitet, pneumoni og influensa er mulige differensialdiagnoser. Det var ikke influensasesong, men det pågikk en mycoplasmaepidemi. Symptomer på atypisk pneumoni er langvarig kraftig tørrhoste, sår hals og hodepine, men pasienten hadde verken hoste eller sår hals.

Sjeldnere differensialdiagnoser ble vurdert som lite sannsynlige. Han hadde lav risiko for lungeemboli og ingen stikkende smerter ved inspirasjon. Fraværet av smerter gjorde også pneumothorax og pleuritt lite sannsynlig. I tillegg hadde han sidelik respirasjonslyd. Ved tuberkulose ville vi ha forventet hoste, noe han ikke hadde. Han hadde ikke hjerteproblemer, og det var ikke mistanke om hjertesvikt.

På grunn av en svak mistanke om atypisk pneumoni, og fordi behandlende lege opp- levde et ønske om antibiotikabehandling fra far og sønn, ble pasienten satt på erytromycin $250 \mathrm{mg} \times 4$ i sju dager. Gutten hadde penicillinallergi, men det var ikke av betydning for antibiotikavalget, da Mycoplasma pneumoniae var mistenkt agens. Til tross for tungpustethet som kontaktårsak, oppfattet man ikke objektivt pustebesvær ved undersøkelse. Antydning til obstruktive lungefysikalia gjorde at han likevel fikk resept på salbutamolinhalator.

Bronkitt og pneumoni er hyppige årsaker til tungpustethet. Bronkitt skyldes i all hovedsak virus, mens pneumoni hos voksne oftest er forårsaket av bakterier. Vanligste agens utenfor sykehus er Streptococcus pneumoniae, etterfulgt av Chlamydophila pneumoniae og virus samt $M$. pneumoniae i epidemier med noen års mellomrom. Hos barn over tre måneder er etiologien omvendt, med virus som vanligste agens. Bakterier dominerer hos de aller yngste.

Bakteriell pneumoni skal alltid behandles med antibiotika. Siden $S$. pneumoniae oftest er årsaken, er førstevalget fenoksymetylpenicillin både til voksne og barn. Ved penicillinallergi eller stor sannsynlighet for M. pneumoniae eller C. pneumoniae er doksysyklin eller erytromycin anbefalt til voksne, og erytromycin til barn. Hos pasienter med nedsatt immunforsvar eller kronisk obstruktiv lungesykdom (kols) er amoksicillin anbefalt (1).

I allmennpraksis har vi sjelden svar på etiologisk agens før eventuelt flere dager etter konsultasjon. Til å hjelpe oss i diagnostikken har vi sykehistorien, klinisk undersøkelse og C-reaktivt protein (CRP). CRP stiger de første 1-2 døgnene. Verdier under 20 taler mot en bakteriell infeksjon, mens verdier over 75-100 trekker $i$ retning av bakteriell infeksjon. I mellomsjiktet er det mer usikkert. CRP-verdier helt ned mot 20 kan ses ved chlamydia- og mycoplasmapneumoni, mens verdier på 50-100 ses både ved influensa og akutt bronkitt (1). Vår pasient hadde CRP på 11 , som taler for viralt agens. Imidlertid hadde han vært syk kun ett døgn, og CRP-verdien ga derfor ikke noe sikkert holdepunkt for dette.

\author{
Lene M. $\emptyset$. Loose \\ lenelos@yahoo.no \\ Allmennlegevakten \\ Legevakten i Oslo \\ og \\ Nydalen legesenter \\ Erlend Elde \\ Allmennlegevakten \\ Legevakten i Oslo
}

Marcus Bubandt Arentz Aune

Allmennlegevakten Legevakten i Oslo og

Nydalen legesenter

Odd Martin Vallersnes

Allmennlegevakten

Legevakten i Oslo

og

Institutt for allmennmedisin Universitetet i Oslo

Engelsk oversettelse på www.tidsskriftet.no

> Se kommentar side 1147 


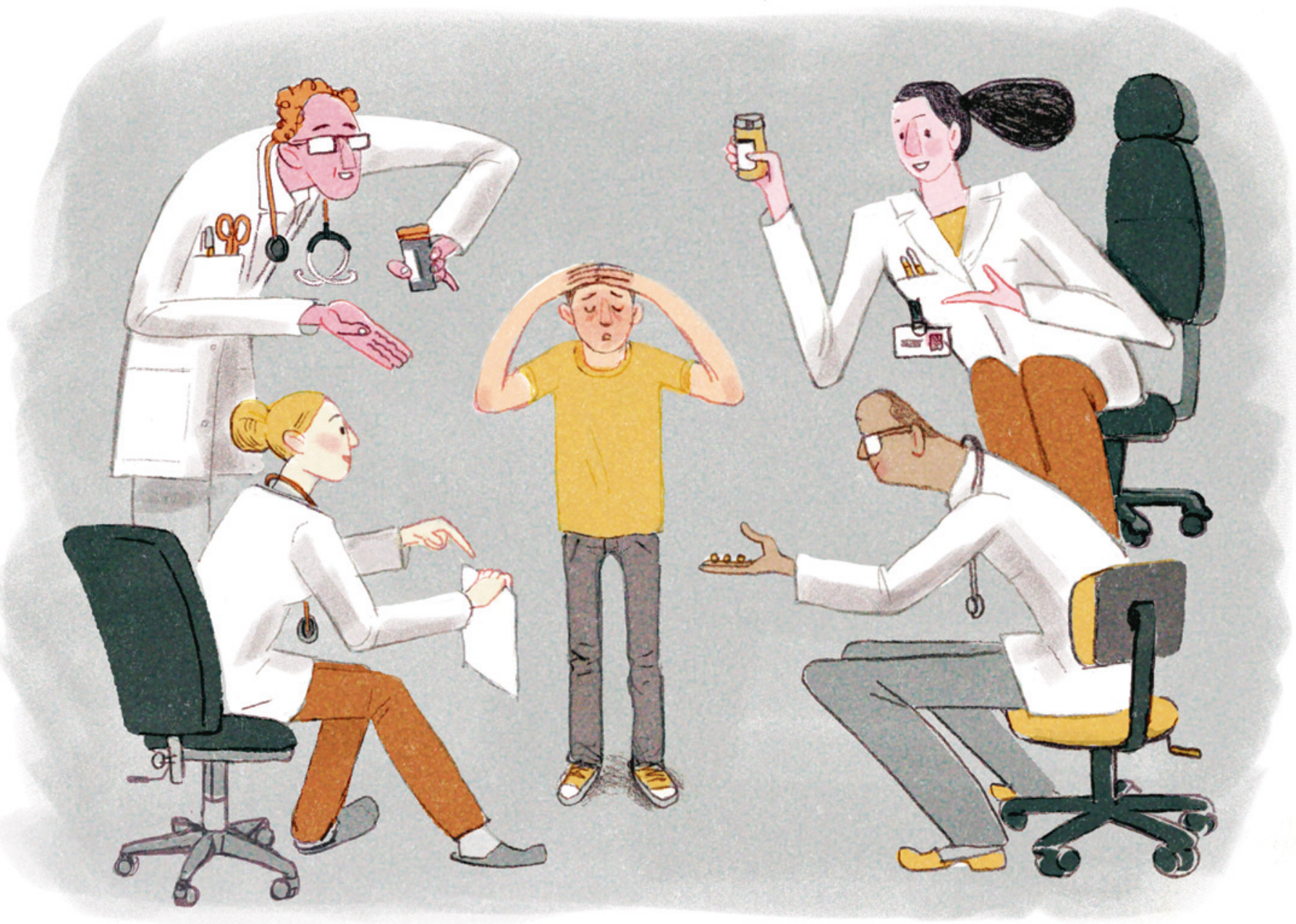

Illustrasjon @ Åshild Irgens

Det ble ikke gjort toppstrømshastighetsmåling (peak expiratory flow, PEF) eller røntgen thorax, selv om begge deler er tilgjengelig ved legevakten. Røntgen thorax forbeholdes tilfeller der det har behandlingsmessig konsekvens - som ved mistanke om pneumothorax eller der påvisning av et infiltrat vil avklare en usikker diagnose. Toppstrømshastighetsmåling gjøres sjelden, siden nytteverdien begrenses av at pasientens normalverdier som regel er ukjente.

To dager etter første konsultasjon kom pasienten og hans far tilbake til legevakten. Da hadde gutten hatt kraftig oppkast og diaré $i$ to døgn. Han kastet opp hver gang han forsøkte å drikke. Han var slapp, men oppegående. Han hadde nå ingen luftveissymptomer. Det var ikke blod eller slim i avføringen, og han hadde ikke magesmerter. Det var ingen andre syke i nærmiljøet, og han hadde ikke vært ute og reist. Han hadde fortsatt lavgradig feber på $38^{\circ} \mathrm{C}$ målt i øret. Respirasjonsfrekvensen og oksygenmetningen var normale. Over lungene hørtes ingen fremmedlyder. Buken var ikke øm, og det var ingen palpable oppfylninger eller hepatosplenomegali. CRP-verdien var 12. Han virket lett dehydrert med takykardi $(115 / \mathrm{min})$ og ketonuri (3+ på urinstiks).

Vanlige årsaker til oppkast og diaré er viral gastroenteritt, bakterielle tarminfeksjoner, matforgiftning og bivirkning av antibiotika. Makrolider som erytromycin er kjent for å gi plager fra gastrointestinalkanalen. Oppkast og diaré ble oppfattet som bivirkninger fra erytromycin. Antibiotika ble seponert, da pneumonidiagnosen ble vurdert som lite sannsynlig. Han fikk resept på kvalmestillende metoklopramid (20 mg suppositorier inntil tre ganger per døgn).

Tre dager etter første konsultasjon kom gutten og faren tilbake på nytt. Nå hadde pasienten igjen tungpustethet og hjertebank. Oppkast vedvarte, men kun én gang daglig. Han hadde drukket greit, men spiste minimalt.
Pulsen var regelmessig, med frekvens 120/ minutt. EKG viste $T$-inversjoner i nedre og laterale avledninger, det var sinusrytme og ingen breddeøkning av QRS-kompleksene. Han hadde mild takypné (frekvens 20/min) med dyp respirasjon. Det var ingen acetonlukt av munnen. Urinstiks viste som før ketoner +3 , blodglukose $5,2 \mathrm{mmol} / \mathrm{l}(3,9-6,9)$ og hemoglobin $15,0 \mathrm{~g} / \mathrm{dl}(11,0-16,0)$. Røntgen thorax, som ble tatt ved denne tredje rekontakten, var normalt.

Den vanligste årsaken til ketonuri er oppkast/diaré og faste. I tilfeller med samtidig glukosuri, tungpustethet eller sløvet bevissthet er diabetisk ketoacidose en nærliggende diagnose. Han hadde normalt blodsukker og ingen glukosuri. Dermed var diagnosen avkreftet. EKG-funnet ble vurdert som uten betydning.

Legen konfererte med barnelege på telefon, og pasienten fikk tilbud om observasjon på sykehus. Han ønsket ikke dette og dro hjem 
med beskjed om å fortsette å ta metoklopramid og ta kontakt med lege ved forverring.

Fem dager etter første konsultasjon kom pasienten tilbake. Gutten ble denne gangen innskrevet med kontaktårsak «ryggsmerter - står i bue». Pasienten fortalte at han samme dag hadde fått vondt $i$ overkroppen på ryggsiden og brystet og at kroppen innimellom inntok stillinger utenfor hans kontroll. Under konsultasjonen fikk han et anfall der han bøyde hodet og ryggen bakover i bue og gråt av smerte. Han hadde kastet opp fra sykdomsdebut til denne dagen og hadde brukt metoklopramid $20 \mathrm{mg}$, tre suppositorier daglig i to dager mot kvalme og oppkast.

Han ble henvist til barneavdeling med tentativ diagnose dystoni som bivirkning av metoklopramid. På sykehuset ble han undersøkt poliklinisk uten funn av alvorlig nevrologisk lidelse. Han fikk biperiden intramuskulært mot dystonisk reaksjon på metoklopramid, med god effekt.

Dystoni er ufrivillige bevegelser, typisk av vridende eller repetitiv karakter. Tilstanden kan opptre ved alvorlige genetiske sykdommer som debuterer i barndom/ungdom. Dystonier kan også utløses sekundært av multippel sklerose, encefalitt, parkinsonisme eller av legemidler som for eksempel metoklopramid.

Neste dag kom pasienten tilbake til legevakten. Det var gått seks dager siden første konsultasjon. Hjertebank var kontaktårsaken denne gangen. Han hadde ikke kastet opp denne dagen og fikk i seg mat. Mild takykardi med frekvens på 110/minutt var eneste unormale funn ved undersøkelse, pulsen var regelmessig og ingen bilyd hørtes over hjertet. EKG var normalt, og beroligende beskjed ble gitt. Han dro hjem uten videre tiltak. De pårørende opplyste seks måneder senere at gutten er frisk og ikke bruker medisiner.

\section{Diskusjon}

Av dem som oppsøker lege med luftveisinfeksjon behandles en tredel med antibiotika. Av dem som behandles, får $41 \%$ fenoksymetylpenicillin, de resterende $59 \%$ får i all hovedsak makrolidantibiotika. Forskrivningspraksisen synes å avvike fra retningslinjene både ved høyere forskrivningsrate og ved at flere får mer bredspektret antibiotika enn anbefalt (2). Bronkitt skal etter retningslinjene ikke behandles med antibiotika, da det oftest skyldes virus (1). I Norge behandles likevel mer enn halvparten av dem med bronkittdiagnose med antibiotika (2). Barn med luftveisinfeksjoner får hyppigere makrolider og bredspektret antibiotika enn voksne. God smak på miksturen gir bedre etterlevelse, og er en sannsynlig forklaring på dette (3).

Hvorfor skriver leger ut antibiotika i tvils- tilfeller? I en islandsk studie (4) ble usikkerhet rundt agens og diagnose og kort tid til å observere pasienten oppgitt som grunner til å forskrive antibiotika. Det ble trukket frem at uenighet mellom pasient og lege om hvorvidt antibiotikabehandling er nødvendig, kan ha en uheldig effekt på lege-pasientrelasjonen. At det er bedre å behandle enn «ikke å gjøre noe», og at det ikke å forskrive antibiotika kan oppleves som at legen ikke viser forståelse for pasientens plager, ble brukt som forklaring av noen. Dersom legen hadde dårlig erfaring med et uheldig forløp hos en tidligere pasient, kunne det være grunn til å gi behandling for å «sikre seg». Pasient og pårørendes forventning om antibiotika og tidspress var også anførte grunner. Tilsvarende er funnet $i$ flere studier (5-8). Interessant nok var det i flere tilfeller ikke samsvar mellom legens tolkning og pasientens/pårørendes ønske.

På legevakt der pasienten møtes av stadig nye og ofte unge leger, er det usikkerhet både hos pasient og lege. Legen kan sikre situasjonen ved å be pasienten komme tilbake ved forverring. Vår pasient burde fått grundigere forklaring av det forventede sykdomsforløpet og blitt oppfordret til å oppsøke fastlege fremfor legevakt ved manglende bedring. Kommunikasjonstrening i å gi god informasjon om antibiotika, forventet sykdomsforløp og når man bør rekontakte lege, er vist å gi høyere aksept for lavere forskrivningsrate blant pasientene (9).

Denne pasienten ble av behandlende leger oppfattet som subjektivt plaget og med forventning om antibiotikabehandling. Han virket engstelig, og legene tolket dette som et ønske om behandling for å være på den sikre siden. Pasienten kom stadig tilbake til legevakten, og sammen medvirket disse faktorene til overbehandling. Behandlingen førte til kraftige bivirkninger med oppkast, kvalme, diaré og dehydrering. Følelsen av hjertebank kan ha vært en bivirkning av salbutamol eller symptom på dehydrering eller stress.

I stedet for kun å seponere antibiotika, fikk han også utskrevet metoklopramid mot oppkast og kvalme. Man skal tenke seg nøye om før man behandler medikamentbivirkninger med nye medikamenter. Dystoni er en vanlig bivirkning av metoklopramid og rammer mellom 1/10 og 1/100. Barn er spesielt utsatt, og metoklopramid skal doseres lavere til barn frem til fylte 15 år (10). I vårt tilfelle fikk gutten beklageligvis voksen dosering.

Han hadde tidligere vært bredt utredet tross sin unge alder, uten at det var funnet noe galt. I epikrisen, som vi i ettertid innhentet fra sykehuset, stilte man spørsmål om plagene hans kunne være psykogene, men vi har ikke opplysninger fra fastlegen angående videre oppfølging der. Usikkerhet og sykdomsangst hos pasienter kan av legen mistolkes som et press om utredning og aktiv behandling. Samtidig kan pasientens usikkerhet rundt egen helse føre til gjentatte kontakter med helsevesenet. Rekontakter er et signal som leger er opplært til å ta på alvor. Resultatet blir dermed ofte omfattende utredning, henvisning til annenlinjetjenesten, eller overbehandling, som også skjedde her.

EKG-funnene hos denne pasienten var uspesifikke og hadde sannsynligvis ingen betydning. Tidligere hjerteutredning hadde konkludert med at han var hjertefrisk. Dette viser noe av problemet ved å foreta stadig nye undersøkelser. Ved hver undersøkelse er det muligheter for å finne avvik som snarere fører til større usikkerhet enn nærmere bestemmelse av en diagnose (11).

Hos denne pasienten var det unødvendig med antibiotika. Med kort sykehistorie var det for tidlig å mistenke atypisk pneumoni, og en CRP-verdi på 11 ga ikke holdepunkt for bakteriell luftveisinfeksjon.

Er det negative konsekvenser av restriktiv forskrivningspraksis? Det er funnet marginalt høyere forekomst av mastoiditt $\mathrm{i}$ land med mindre forskrivning av antibiotika (12). Det er vist at $0,5-1,5 \%$ av pasienter med bronkitt som ikke fikk antibiotika, kontaktet lege igjen med behandlingstrengende pneumoni (13). I én studie (14) ble det vist mulig lett økt dødelighet av pneumoni utenfor sykehus ved strengere forskrivningspraksis, men denne studien er kritisert for alvorlige metodologiske mangler (12).

Vi tror det var frykt for komplikasjoner og for at pasienten ikke skulle ta kontakt med lege ved forverring, som var hovedgrunnene til overbehandling $\mathrm{i}$ vårt tilfelle. Vi tror videre at dette er viktige årsaker til forskrivning i mange tvilstilfeller. En studie viste at pasientene var like fornøyde uten som med antibiotika (7), men det krever mer tid ikke å forskrive. Det er også vist korrelasjon mellom en travel lege og høyere forskrivningsrate (2).

Det tar tid å trygge pasienter og pårørende ved å gi god informasjon, forsikre seg om at de forstår informasjonen og kan ta ansvar for å søke lege på nytt om tilstanden forverres og forløpet ikke blir som forventet. Det er synd hvis leger skriver ut antibiotika for å være «hyggelige» mot pasienten uten en gang å vite om pasienten er interessert $\mathrm{i}$ behandling på tynt grunnlag og «for alle tilfellers skyld». Det kan, som her, føre til overbehandling og unødvendig ubehagelig forløp for pasienten. Samfunnsmessig har det også store negative konsekvenser med økt antibiotikaresistens. I tvilstilfeller kan et klargjørende tiltak være å spørre pasienten hva han/hun tenker om behandling.

Den siste legen skriver i notatet fra konsul- 
tasjonen at han har gitt beroligende beskjed om at kroppen helt fint klarer å fikse dette uten medisiner. Dette ble den siste konsultasjonen. God og trygg informasjon er ofte god behandling. I vår iver etter å være handlekraftige leger må vi ikke glemme vår forpliktelse til ikke å skade. Å gjøre såkalt «ingenting» er også å gjøre noe.

Pårørende og pasienten har gitt samtykke til at artikkelen blir publisert.

\section{Lene M. Ø. Loose (f. 1978)}

er lege i spesialisering i allmennmedisin, fastlegevikar ved Nydalen Legesenter i Oslo og ved Allmennlegevakten.

Forfatter har fylt ut ICMJE-skjemaet og oppgir ingen interessekonflikter.

\section{Erlend Elde (f. 1982}

er lege i spesialisering i allmennmedisin og legeskiftleder ved Allmennlegevakten.

Forfatter har fylt ut ICMJE-skjemaet og oppgir ingen interessekonflikter.

\section{Marcus Bubandt Arentz Aune (f. 1979)}

er lege i spesialisering i allmennmedisin og fastlegevikar ved Nydalen Legesenter.

Forfatter har fylt ut ICMJE-skjemaet og oppgir ingen interessekonflikter.

\section{Odd Martin Vallersnes (f. 1969)}

er spesialist i allmennmedisin, legeskiftleder ved Allmennlegevakten og ph.d.-stipendiat.

Forfatter har fylt ut ICMJE-skjemaet og oppgir ingen interessekonflikter.

\section{Litteratur}

1. Antibiotikabruk i primærhelsetjenesten. Nasjonale faglige retningslinjer. https://helsedirektoratet.no/ retningslinjer/nasjonal-faglig-retningslinje-forantibiotikabruk-i-primerhelsetjenesten (7.4.2015).

2. Gjelstad S, Straand J, Dalen I et al. Do general practitioners' consultation rates influence their prescribing patterns of antibiotics for acute respiratory tract infections? J Antimicrob Chemother 2011; 66: 2425-33.

3. Fossum GH, Lindbæk M, Gjelstad S et al. Are children carrying the burden of broad-spectrum antibiotics in general practice? Prescription pattern for paediatric outpatients with respiratory tract infections in Norway. BMJ Open 2013; 3: 1.

4. Petursson P. GPs' reasons for «non-pharmacological» prescribing of antibiotics. A phenomenological study. Scand J Prim Health Care 2005; 23 $120-5$

5. Little $\mathrm{P}$, Dorward M, Warner $\mathrm{G}$ et al. Importance of patient pressure and perceived pressure and perceived medical need for investigations, referral, and prescribing in primary care: nested observational study. BMJ 2004: 328: 444.

6. Cockburn J. Pit S. Prescribing behaviour in clinical practice: patients' expectations and doctors' perceptions of patients' expectations-a questionnaire study. BMJ 1997; 315: 520-3.

7. Hamm RM, Hicks RJ, Bemben DA Antibiotics and respiratory infections: are patients more satisfied when expectations are met? J Fam Pract 1996; 43 : $56-62$.
8. Soma M, Slapgård H, Lerberg M et al. Pasienters forventninger om antibiotika ved symptomer pa luftveisinfeksjon. Tidsskr Nor Lægeforen 2005; 125: $1994-7$

9. Cals JW, Butler CC, Hopstaken RM et al. Effect of point of care testing for $C$ reactive protein and training in communication skills on antibiotic use in lower respiratory tract infections: cluster randomised trial. BMJ 2009; 338: b1374

10. Felleskatalogen 2014. www.felleskatalogen.no/ medisin/substansregister/metoklopramid (7.4.2015).

11. Welch HG, Schwartz L, Woloshin S. Overdiagnosed: making people sick in the pursuit of health Boston: Beacon Press, 2011

12. Goossens H, Ferech M, Vander Stichele R et al. Outpatient antibiotic use in Europe and association with resistance: a cross-national database study. Lancet 2005; 365: 579-87.

13. Gonzales R, Steiner JF, Lum A et al. Decreasing antibiotic use in ambulatory practice: impact of a multidimensional intervention on the treatment of uncomplicated acute bronchitis in adults. JAMA 1999; 281: 1512-9.

14. Price DB, Honeybourne D, Little P et al. Community-acquired pneumonia mortality: a potential link to antibiotic prescribing trends in general practice. Respir Med 2004; 98: 17-24

Mottatt 4.12. 2014, første revisjon innsendt 2.2. 2015, godkjent 7.4. 2015. Redaktør: Lise Mørkved Helsingen.

\section{Kommentar}

\section{Uvanlig om det vanlige}

Kasuistikker i medisinske tidsskrifter handler gjerne om sjeldne tilstander, som takket være kløktige leger blir korrekt diagnostisert og suksessfullt behandlet. Kasuistikken til Loose og medarbeidere er helt motsatt. Den omhandler en svært vanlig tilstand som blir gjenstand for en svært vanlig overbehandling. Sjeldenheten dreier seg om at pasienten var trippelt uheldig: Han fikk en unødvendig behandling, bivirkninger av denne behandlingen, og så bivirkninger av behandlingen for bivirkningene. Sjeldent er også forfatternes mot. De eksponerer egne vurderinger og valg som viser seg ikke å være så gode. Alle gjør feil, men få velger å skrive om dem. Dette er til å lære av både for forfatterne selv og for leserne.

Overbehandling med antibiotika ved luftveisinfeksjoner i allmennpraksis forekommer hyppig. En ny nederlandsk studie der man undersøkte symptomer, funn og forskrivningspraksis ved luftveisinfeksjoner, viste at $46 \%$ av pasientene som fikk antibiotika, ikke burde hatt dette ifølge de nasjonale retningslinjene for antibiotikabruk (1). Nederland har langt lavere antibiotikabruk enn Norge (2), og det er grunn til å tro at overforbruket er like høyt i norsk allmennpraksis. Et visst overforbruk er på sett og vis forståelig. Tidspress, opplevde forventninger fra pasienten og den diagnostiske usikkerheten som er en uunngåelig del av det å praktisere medisin i primærhelsetjenesten, medfører ofte en antibiotikaresept «for sikkerhets skyld». Både pasient og lege er interessert $\mathrm{i}$ at problemet blir forsøkt løst her og nå. Samtidig er overforbruket høyst uønsket, både fordi det gir individuelle bivirkninger på kort sikt og samfunnsmessige bivirkninger på lengre sikt.
Det finnes gode metoder for å redusere overforbruket av antibiotika i allmennpraksis. En metode som både gir redusert forskrivning og riktigere valg av antibiotika (3), har på sett og vis samme virkemiddel som Loose og medarbeidere har valgt: å eksponere egen praksis. Når allmennleger går gjennom egen forskrivning og diskuterer denne med kolleger, oppstår læring og endring.

Forfatterne angir at en pågående mycoplasmaepidemi virket inn på behandlingsvalget. Den forrige store mycoplasmaepidemien i 2011 medførte et betydelig overforbruk av makrolidantibiotika (4). Legene syntes å behandle pasienter med positiv polymerasekjedereaksjonstest (PCR) på M. pneumoniae uavhengig av om de hadde symptomer og funn svarende til pneumoni. Til den neste epidemien som sannsynligvis 